\title{
STRAWBERRY YIELD SUBMITTED TO DIFFERENT ROOT PRUNING INTENSITIES OF TRANSPLANTS ${ }^{1}$
}

\author{
CARINE COCCO ${ }^{2}$, LETÍCIA VANNI FERREIRA³, MICHÉL ALDRIGHI GONÇALVES ${ }^{4}$, \\ LUCIANO PICOLOTTO ${ }^{5}$, LUIS EDUARDO CORREAA ANTUNES ${ }^{6}$
}

\begin{abstract}
This study aimed to evaluate the growth of plants and the precocity of strawberry production under different root pruning intensities at planting time. Bare roots plants with 12 millimeters crown diameter produced in nurseries from the Patagonia region, Argentina were used. The planting was carried out on May $12^{\text {th }} 2010$ into experimental plots with non-fumigated soil. The treatments consisted of three cultivars (Camarosa, Florida Festival and Camino Real) and three pruning intensities (1/3, 2/3 and no pruning) on the total root length of the plants. The experimental design used was a randomized block design in a $3 \times 3$ factorial arrangement with three replications and 12 plants per plot and density of 11.1 plants $\mathrm{m}^{-2}$. Mature fruits were harvested from July $15^{\text {th }}$ to December $14^{\text {th }} 2010$ and the production of fresh fruit was determined. There was no significative interaction between cultivars and pruning intensity. 'Camarosa' and 'Florida Festival' plants showed precocity and had the most abundant and heavier fruits during the precocity period. The different root pruning intensities did not affect the assessed variables. It was concluded that, in order to facilitate strawberry planting of the cultivars Camarosa, Florida Festival and Camino Real root pruning is possible, with no damages on plant growth and development, precocity and early fruit production.
\end{abstract}

Index terms: Fragaria x ananassa, bare root plants, advanced production, root system length, plant quality.

\section{PRODUTIVIDADE DO MORANGUEIRO SUBMETIDO A DIFERENTES INTENSIDADES DE PODA DO SISTEMA RADICULAR}

RESUMO - O objetivo deste estudo foi avaliar o crescimento de plantas e a precocidade de produção do morangueiro submetido a diferentes intensidades de poda do sistema radicular, no momento do plantio. Foram utilizadas mudas de raízes nuas produzidas em viveiros, na região da Patagônia Argentina, com diâmetro médio da coroa de 12 milímetros. O plantio foi realizado em 12 de maio de 2010, em parcelas experimentais, em solo não fumigado. Os tratamentos abrangeram três cultivares (Camarosa, Florida Festival e Camino Real) e três intensidades de poda (1/3, 2/3 e sem poda) sobre o comprimento total de raízes das mudas, em esquema fatorial $3 \times 3$, em delineamento experimental de blocos ao acaso, com três repetições, 12 plantas por parcela e densidade de 11,1 plantas por $\mathrm{m}^{2}$. As frutas foram colhidas maduras, no período entre 15 de julho a 14 dezembro de 2010, sendo determinada a produção de fruta fresca. Não houve interação significativa entre cultivares e intensidades de poda. As plantas das cultivares 'Camarosa' e 'Florida Festival' foram mais precoces e tiveram maior número e peso das frutas durante o período considerado precoce. As diferentes intensidades de poda do sistema radicular não influenciaram as variáveis avaliadas. Concluímos que, para facilitar o plantio de muda de morangueiro das cultivares Camarosa, Florida Festival e Camino Real, é possível fazer a poda do sistema radicular sem prejuízos no crescimento e desenvolvimento das plantas, na precocidade e na produção precoce de frutas.

Termos para indexação: Fragaria $x$ ananassa, mudas com raízes nuas, produção precoce, comprimento do sistema radicular, qualidade de mudas.

\footnotetext{
'(Trabalho 085-12). Recebido em: 01-02-2012. Aceito para publicação em: 10-08-2012.

${ }^{2}$ Eng. Agr. Doutoranda em Fruticultura de Clima Temperado, UFPel, Pelotas - RS, Brasil. Bolsista CNPq. E-mail: carinecocco@ yahoo.com.br

${ }^{3}$ Eng. Agr. Mestranda em Fruticultura de Clima Temperado, UFPel, Pelotas - RS, Brasil. Bolsista CAPES. E-mail: letivf@hotmail.com ${ }^{4}$ Eng. Agr. Doutorando em fruticultura de Clima Temperado, UFPel, Pelotas - RS, Brasil. Bolsista CAPES. E-mail: aldrighimichel@ gmail.com

${ }^{5}$ Eng. Agr. Dr. Bolsista PNPD/CAPES/Brasil. E-mail: picolotto@gmail.com

${ }^{6}$ Eng. Agr. Dr. Embrapa Clima Temperado. Rodovia BR 392, Km 78, CEP 96010-971, Pelotas - RS, Brasil. Bolsista CNPq PQ. E-mail: luis.antunes@embrapa.br
} 
Bare root plants are used in the establishment of cultivated fields in the annual strawberry production system in Rio Grande do Sul, Brazil. The success of the bare roots plants establishment requires an adequate depth planting. This precaution is very important since it is necessary to assure that root system is completely covered and crown base is on contact with soil (ANTUNES; DUARTE FILHO, 2005).

Chile and Argentina present adequate characteristics to production, such as elevated latitudes, low precipitation, and mild summers with expressive reduction of the night temperature, sandy soils and abundant solar radiation (OLIVEIRA et al., 2006). These characteristics are favorable to plant production of high genetic, phytosanitary and physiological quality, which confers to the plant high productive potential. Plants imported from Chile and Argentina exhibit a root system with 20 to $30 \mathrm{~cm}$ length, large volume and are transplanted into raised beds covered with a black polyethylene. Generally, the volume of roots exceeds the size of the planting hole, requiring root bending or twisting which makes the planting difficult. Besides, a reduction of water and nutrients uptake due to root twisting might occur, causing stress and even plant death.

At planting stage, most growers use tools to dig a $15 \mathrm{~cm}$ depth hole in the raised bed. However, plants further vary in size and usually these planting holes are not large enough to accommodate the root system of the largest plants. Therefore, some growers prune part of the root system. Part of the plant reserves that would be used to plant development could be lost by root pruning, leading to a reduction in plant growth rate because the plants need to emit new roots to assure the growth and development of the aerial part. The study aimed to evaluate the growth, precocity and production of three strawberry cultivars submitted to different root pruning intensities.

This research was carried out in an experimental field of Embrapa Temperate Climate, located in Pelotas, state of Rio Grande do Sul, Brazil, coordinates $31^{\circ} 40^{\prime} 41.29^{\prime \prime} \mathrm{S}$ and $52^{\circ} 26^{\prime} 22.05^{\prime \prime} \mathrm{W}$, altitude of $70 \mathrm{~m}$. The experiment was performed from May 12th to December 14th, 2010, using bare root plants from Argentina, with an average crown diameter of $12 \mathrm{~mm}$.

The strawberries plants were grown under conventional cultivation in $1.10 \mathrm{~m}$ with polyethylene mulched raised beds, with a plant density of 11.1 plants $\mathrm{m}^{-2}(0.30 \times 0.30 \mathrm{~m})$, under low $100 \mu \mathrm{m}$ polyethylene tunnels. In sunny days, tunnels were opened at sunrise and closed at sunset and inverse on cloudy or rainy days that tunnels were kept closed. Basal fertilizing and $\mathrm{pH}$ correction of the experimental area were carried out according to the recommendations for the crop (SBCS, 2004). Water and nutrients were supplied by drip irrigation based on recommendations from Santos e Medeiros (2003).

The treatments comprised three cultivars (Camarosa, Florida Festival and Camino Real) and three pruning intensities on total roots length: $1 / 3$ pruning, 2/3pruning and no pruning of the root system, keeping in average 6,12 and $18 \mathrm{~cm}$ of length, respectively. The experimental design used was a randomized block design in a $3 \times 3$ factorial arrangement with three replications and 12 plants per plot. Number of days from planting to the beginning of flowering and to the first fruit harvest was recorded when $50 \%$ of the plants in the plot had at least one flower and one ripe fruit, respectively. Ripe fruits were harvested twice a week at $100 \%$ red epidermis. At each harvest, fruits were counted and weighted. Mean fruit weight was calculated by the ratio between number and total fresh weight. It was also determined the accumulated production of fruits. Only sellable fruits were considered; damaged and rotten fruits or lighter than $3 \mathrm{~g}$ were discarded (CEAGESP, 2002). Early fruit production was considered from the beginning of the harvest to September $30^{\text {th }}$, 2010, and total fruit production, from the beginning of the harvest to December 14th, 2010. At beginning of flowering and at the end of the experiment, three plants of each treatment were removed from the soil. The crown diameter, number of crowns and number of leaves were measured and counted and dry mass of shoot was determined after drying at $65^{\circ} \mathrm{C}$ until constant mass was recorded. Dry mass was weighed using a digital balance. The fulfillment of assumptions about the mathematical model for analysis of variance was verified by the error normality test. All variables were submitted to analysis of variance and the significance of differences among means was determined by the Tukey's test at 5\% probability.

The production of the three strawberry cultivars lasted from July to December, totalizing 22 weeks. This trial was carried out under great post-transplantation conditions. The irrigation was kept above field capacity in the first weeks after transplantation, which allowed the surviving rate of the plants. Plant survival after planting in plants from three cultivars and intensity of pruning did not differ. Plant survival was $98.9 \%$ (data not shown).

There was no significant interaction between cultivar and root pruning intensity for the evaluated variables. Earlier fruit harvest was recorded for plants from 'Camarosa', with beginning of production in 89 days after planting (Table 1); similar to what was 
observed by Oliveira et al. (2006). This confirms the precocity characteristic described by Coelho Júnior et al. (2010). In the strawberry production system and commercialization, early production is an important characteristic since the best prices of the fruits are possible from May to July (CAMARGO FILHO, 1994; DUARTE FILHO et al., 1999). The different intensity of the strawberry root pruning did not affect precocity of the fruit production not being the mechanism that regulates this event. According to Silva et al. (2007) the occurrence of this differentiation, which results in flowering, depends on multiple factors and the environmental ones are of major importance. However, temperature, photoperiod and their interaction show also great relevance.

Crown diameter and root dry mass did not differ among cultivars $\left(13.6 \mathrm{~mm}\right.$ and 2.1 grams plant $^{-1}$, respectively). However, dry mass of the aerial part at full bloom was superior in plants of 'Camarosa' (9.0grams plant ${ }^{-1}$ ), being $34.3 \%$ and $95.6 \%$ superior to plants of 'Florida Festival' and 'Camino Real', respectively. At the experiment conclusion the differences among cultivars regarding dry mass of the aerial part were reduced. Plants of 'Camino Real' present less shoot dry mass (aerial part), meaning 25.3 grams plant $^{-1}$ and differing from other cultivars (Table 1). Silva et al. (2007) describe 'Camino Real' as a cultivar of small size, more compact, straight and less vigorous than 'Camarosa' which Strassburger et al. (2011) observed as the cultivar with the highest index of foliar area. At the end of the experiment, the number of crowns was superior in plants of ' $\mathrm{Ca}$ marosa', around 5.6 crowns per plant. 'Festival' and 'Camino Real' showed in average 3.8 and 4.3 crowns per plant, respectively. Diameter of crown was superior in the cultivar 'Festival' $(23.2 \mathrm{~mm}), 33.35 \%$ larger than 'Camarosa' and $17.7 \%$ than 'Camino Real'. The number of leaves per plant at the experiment conclusion did not differ among the three cultivars (30.9 leaves per plant). Durner et al. (2002) concluded that the number of crowns per plant is the more expressive factor associated to production per hectare. Generally, there is a positive correlation among production and number of fruits, number of inflorescences, number of leaves and number of crown per plants.

The different pruning intensities of the strawberry roots did not influence the vegetative growth and development of the plants, except the diameter of the crown at the end of the experiment that was superior on plants that had two thirds of the roots pruned (Table 1).

The early fruit production expressed in number and fresh mass was lower in plants of 'Camino Real' ( 6.2 fruits and 122.8 grams plant $^{-1}$, respectively)
(Table 2). No differences were verified between the other cultivars. The mean size of fruits in the precocity period was superior in plants of 'Camarosa' with 23.1 grams per fruit. At the experiment conclusion, 'Camarosa' had the higher number of fruits and total fresh mass (58.1 fruits and 954.7grams); plants of 'Festival' were $17 \%$ and $24 \%$ inferior to 'Camarosa', respectively, and for the 'Camino Real' the difference was even higher, $46.8 \%$ and $59.8 \%$, respectively. The higher plant dry mass of the cultivar 'Camarosa' observed in this study and by Strassburger et al. (2011) probably induced the large expansion of the photosynthetic system that improves the interception of the solar radiation and photoassimilates production, an important factor to flowering and plant production.

The pruning of the strawberry root at planting did not affect the early fruit production in number, fresh mass and fruit weight. However, in the total production the number of fruits was influenced by the different pruning intensities. The higher number of fruits was observed in plants that were not rooting pruned, not differing from plants that had one-third of the root pruned. The variations of root pruning did not influence the growth variables, development, production and fruit size of the three cultivars studied.

In case of no root pruning, plants with root twisting may show limited capacity of nutrients uptake, since deformed parts could offer resistance to water and nutrient flow. Also, there may be disequilibrium in the growth regulators, which could compromise the growth and yield (AMOROSO et al., 2010). Some authors have demonstrated that restrictions done to the root system may lead to serious root deformations after planting and low initial growth rates of the aerial part in the field (AMOROSO et al., 2010), resulting in production losses. This effect was not observed in this study because the surviving rate and the dry mass of the aerial part at full bloom did not statistically differ among pruning intensities.

The results of this study attend the results found by other researchers (DUVAL; GOLDEN, 2003; LARSON, 1998). However, the absence of differences among these variables is unexpected due to the intensity of the cut done at the root system before planting. These results suggest that the root system of strawberry shows a considerable capacity of regeneration because of the constant renovation of its roots during all the cycle of the crop. It is possible that this particular effect of rapid regeneration occurs due to the high physiological quality of the plants from the region of Patagonia Argentina.

Possibly, the rapid renovation of the roots 
is associated to the high availability of reserves in the crown (BRÁNDAN et al., 2009). It is believed that the remnant reserves in the roots after pruning would be sufficient to supply the demand at this stage of development.

In the present study, the production of root biomass was not influenced by the different pruning intensities in the plant roots, but it may be related to the ideal conditions of the cultivation. According to Amoroso et al. (2010), the adjustment of the root system is extremely important to the plant establishment, mainly under water deficit because the depth of root and the soil volume exploited by plants is fundamental to assure the plant surviving under limiting conditions.
These results greatly interfere the commercial planting done by the strawberry growers. Losses in the early and total fruit production were not observed regarding the plant root pruning done at the Argentinean nursery at planting phase, neither variation in the post-transplantation productive performance due to pruning intensity. This indicates that strawberry root pruning could be a practice that would facilitate planting and help to reduce the incidence of plants not well transplanted.

It was concluded that the pre-transplantation root pruning of the strawberry did not affect plant growth and earlier fruit production. The cultivars 'Camarosa' and 'Florida Festival' show great precocity of fruit yield.

TABLE 1 - Early of fruits, crown diameter (CD), shoot dry mass (SDM) and root dry mass (RDM) of bare root strawberry at flowering, and average number of leaves (NL), number of crowns (NC), crown diameter (CD) and shoot dry mass (SDM) of plants with different cultivars and root pruning intensity, at the end of the experiment. Embrapa Clima Temperado, Pelotas-RS, 2011.

\begin{tabular}{|c|c|c|c|c|c|c|c|c|}
\hline \multirow[b]{2}{*}{ Cultivars } & \multirow[b]{2}{*}{ Precocity } & \multicolumn{3}{|c|}{ At flowering } & \multicolumn{4}{|c|}{ At end of experiment } \\
\hline & & CD & SDM & RDM & NL & $\mathrm{NC}$ & CD & SDM \\
\hline & days & $\mathrm{mm}$ & g plant $^{-1}$ & g plant $^{-1}$ & & & $\mathrm{~mm}$ & g plant $^{-1}$ \\
\hline Camarosa & $89 b^{*}$ & $13,7 \mathrm{a}$ & $9,0 \mathrm{a}$ & $2,6 \mathrm{a}$ & $50,3 \mathrm{a}$ & $5,6 \mathrm{a}$ & $17,4 \mathrm{c}$ & 33,3 a \\
\hline Festival & $92 \mathrm{ab}$ & $13,0 \mathrm{a}$ & $6,7 \mathrm{~b}$ & $1,9 \mathrm{a}$ & $38,8 \mathrm{a}$ & $3,8 \mathrm{~b}$ & $23,2 \mathrm{a}$ & $34,2 \mathrm{a}$ \\
\hline Camino Real & $97 \mathrm{a}$ & $14,1 \mathrm{a}$ & $4,6 \mathrm{~b}$ & $1,8 \mathrm{a}$ & $36,4 \mathrm{a}$ & $4,3 \mathrm{~b}$ & $19,7 \mathrm{~b}$ & $25,3 \mathrm{~b}$ \\
\hline Average & 92.7 & 13.6 & 6.7 & 2.1 & 41.8 & 4.6 & 20.1 & 30.9 \\
\hline & \multicolumn{8}{|c|}{ Intensity of root pruning at planting } \\
\hline No pruning & $90 \mathrm{a}$ & $14,2 \mathrm{a}$ & $6,9 \mathrm{a}$ & $2,3 \mathrm{a}$ & $44,7 \mathrm{a}$ & $4,8 \mathrm{a}$ & $18,6 \mathrm{~b}$ & $27,8 \mathrm{a}$ \\
\hline $1 / 3$ pruned & $93 \mathrm{a}$ & $13,2 \mathrm{a}$ & $6,8 \mathrm{a}$ & $2,2 \mathrm{a}$ & $39,8 \mathrm{a}$ & $4,9 \mathrm{a}$ & $18,7 \mathrm{~b}$ & $33,3 \mathrm{a}$ \\
\hline $2 / 3$ pruned & $95 \mathrm{a}$ & $13,4 \mathrm{a}$ & $6,5 \mathrm{a}$ & $1,6 \mathrm{a}$ & $41,1 \mathrm{a}$ & $4,0 \mathrm{a}$ & $22,9 \mathrm{a}$ & $31,7 \mathrm{a}$ \\
\hline Average & 92.7 & 13.6 & 6.7 & 2.0 & 41.9 & 4.6 & 20.1 & 30.8 \\
\hline CV (\%) & 7.0 & 15.0 & 28.5 & 30.1 & 33.1 & 20.3 & 5.8 & 34.5 \\
\hline
\end{tabular}

* Means followed by same letter in column do not differ by Tukey test at $5 \%$ probability.

TABLE 2 - Number of fruits (NF), fresh mass of fruits (FMF) and average weight of fruit (AWF) in early and total yield of strawberry plants from bare root with different cultivars and root pruning intensity. Embrapa Clima Temperado, Pelotas-RS, 2011.

\begin{tabular}{lcccccc}
\hline \multirow{2}{*}{ Cultivars } & \multicolumn{3}{c}{ Early yield } & \multicolumn{3}{c}{ Total yield } \\
\cline { 2 - 7 } & NF & FMF & AWF & NF & FMF & AWF \\
\cline { 2 - 7 } Camarosa & $8.8 \mathrm{a}^{*}$ & g plant $^{-1}$ & g fruit $^{-1}$ & \multicolumn{5}{c}{ g plant $^{-1}$} & g fruit $^{-1}$ \\
Festival & $9.7 \mathrm{a}$ & $175.4 \mathrm{a}$ & $23.1 \mathrm{a}$ & $58.1 \mathrm{a}$ & $954.7 \mathrm{a}$ & $16.5 \mathrm{~b}$ \\
Camino Real & $6.2 \mathrm{~b}$ & $122.8 \mathrm{~b}$ & $20.0 \mathrm{~b}$ & $48.2 \mathrm{~b}$ & $725.9 \mathrm{~b}$ & $15.1 \mathrm{c}$ \\
\hline Average & $\mathbf{8 . 2}$ & $\mathbf{1 6 7 . 3}$ & $\mathbf{2 0 . 4}$ & $\mathbf{4 5 . 7}$ & $571.0 \mathrm{c}$ & $18.4 \mathrm{a}$ \\
\hline \multicolumn{4}{c}{ Intensity of root pruning at planting } \\
No pruned & $8.8 \mathrm{a}$ & $179.5 \mathrm{a}$ & $20.7 \mathrm{a}$ & $47.9 \mathrm{a}$ & $789.2 \mathrm{a}$ & $16.8 \mathrm{a}$ \\
1/3pruned & $7.7 \mathrm{a}$ & $159.6 \mathrm{a}$ & $20.7 \mathrm{a}$ & $45.9 \mathrm{ab}$ & $754.7 \mathrm{a}$ & $16.7 \mathrm{a}$ \\
2/3pruned & $8.2 \mathrm{a}$ & $162.9 \mathrm{a}$ & $19.9 \mathrm{a}$ & $43.3 \mathrm{~b}$ & $707.7 \mathrm{a}$ & $16.4 \mathrm{a}$ \\
\hline \multicolumn{1}{c}{ Average } & $\mathbf{8 . 2}$ & $\mathbf{1 6 7 . 3}$ & $\mathbf{2 0 . 4}$ & $\mathbf{4 5 . 7}$ & $\mathbf{7 5 0 . 5}$ & $\mathbf{1 6 . 6}$ \\
\hline CV (\%) & $\mathbf{1 5 . 7}$ & $\mathbf{1 4 . 2}$ & $\mathbf{8 . 1}$ & $\mathbf{7 . 9}$ & $\mathbf{1 0 . 7}$ & $\mathbf{6 . 6}$ \\
\hline
\end{tabular}

*Means followed by same letter in column do not differ by Tukey test at $5 \%$ probability. 


\section{REFERENCES}

AMOROSO, G.; FRANGI, P.; PIATTI, R.; FERRINI, F.; FINI, A.; FAORO, M. Effect of container design on plant growth and root deformation of little leaf linden and field elm. HortScience, Alexandria, v.45, n.12, p.1824-1829, 2010.

ANTUNES, L.E.C.; DUARTE FILHO, J. Produção de mudas de morango. In: SANTOS, A.M. dos; MEDEIROS, A.R.M. Sistema de produção do morango. Pelotas: EMBRAPA CT, 2005. (Sistema de produção, 5). Disponível em: $<$ http://sistemasdeproducao.cnptia.embrapa.br/ FontesHTML/Morango/SistemaProducaoMorango/ cap01.htm>. Acesso em: 18 jul. 2010.

CEAGESP. Normas de classificação de morango. São Paulo: CQH/CEAGESP, 2002. 6 p. (Documento, 22).

COELHO JÚNIOR, J.M.; RESENDE, L.V.; RESENDE, J.T.V.D.; ROLIM NETO, F.C.; JIMENEZ, H.J. Caracterização topográfica dos folíolos medianos de cultivares de morangueiro sob altas temperaturas. Revista Caatinga, Mossoró, v.23, n.3, p.13-18, 2010.

DURNER, E.F.; POLING, E.B.; MAAS, J.L. Recent advances in strawberry plug transplant technology. HortTechnology, Amsterdam, v.12, p.545-550, 2002.

DUVAL, J.R.; GOLDEN, E. Root pruning of strawberry transplants. Gainsville: University of Flórida. 2003. 2 p. (IFAS extension HS913). Disponível em: $<$ http://edis.ifas.ufl.edu/hs149>. Acesso em: 23 jul. 2011.
GIMÉNEZ, G.; ANDRIOLO, J.L.; JANISH, D.J.; COCCO, C.; DAL PICIO, M. Cell size in trays for the production of strawberry plug transplants. Pesquisa Agropecuária Brasileira, Brasília, v.44, p.726-729, 2009.

LARSON, K. Pre-plant root pruning and performance of Camarosa strawberry plants. Gainsville: University of Califórnia, 1998. (Progress Report, 98-23)

LIETEN, F. Recent advances in strawberry plug transplant technology. Acta Horticulturae, The Hague, n.513, p.383-388, 2000.

OLIVEIRA, R.P.; SCIVITTARO, W.B. Desempenho produtivo de mudas nacionais e importadas de morangueiro. Revista Brasileira de Fruticultura, Jaboticabal, v.28, n.3, p.520-522, 2006.

SANTOS, A.M.; MEDEIROS, A.R.M. Morango: produção frutas do Brasil. 40. ed. Pelotas: EMBRAPA Clima Temperado, 2003. 81 p.

SBCS - Sociedade Brasileira ce Ciência Do Solo. Manual de adubação e calagem para os Estados do Rio Grande do Sul e Santa Catarina. Porto Alegre: SBCS/CQFS, 2004. 400p.

STRASSBURGER, A.S.; PEIL，R.M.N.; SCHWENGBER, J.E; MARTINS, D.D.S.; MEDEIROS, C.A.B. Crescimento do morangueiro: influência da cultivar e da posição da planta no canteiro. Ciência Rural, Santa Maria, v.41, n. 2, p.223-226, 2011. 